\title{
The effect of exposure to sulphuric acid on the early asthmatic response to inhaled grass pollen allergen
}

\author{
W.S. Tunnicliffe*, D.E. Evans", D. Mark", R.M. Harrison", J.G. Ayres*
}

\begin{abstract}
The effect of exposure to sulphuric acid on the early asthmatic response to inhaled grass pollen allergen. W.S. Tunnicliffe, D.E. Evans, D. Mark, R.M. Harrison, J.G. Ayres. (C) ERS Journals Ltd 2001.

ABSTRACT: Particulate sulphates, including sulphuric acid $\left(\mathrm{H}_{2} \mathrm{SO}_{4}\right)$, are important components of the ambient aerosol in some areas and are regarded as air pollutants with potentially important human health effects. Challenge studies suggest little or no effect of $\mathrm{H}_{2} \mathrm{SO}_{4}$ exposure on lung function in asthmatic adults, although some epidemiological studies demonstrate an effect of acid species on symptoms in subjects with asthma. To date, the effect of $\mathrm{H}_{2} \mathrm{SO}_{4}$ on allergen responsiveness has not been studied.

The effect of exposure to particulate $\mathrm{H}_{2} \mathrm{SO}_{4}$ on the early asthmatic response to grass pollen allergen has been investigated in 13 adults with mild asthma. After establishment of the provocative dose of allergen producing a $15 \%$ fall in forced expiratory volume in one second (FEV1) (PD15) for each subject, they were exposed to air, $100 \mu \mathrm{g} \cdot \mathrm{m}^{-3}$ or $1,000 \mathrm{~g} \cdot \mathrm{m}^{-3} \mathrm{H}_{2} \mathrm{SO}_{4}$ for $1 \mathrm{~h}$, double-blind in random order $\geqslant 2$ weeks apart, through a head dome delivery system $14 \mathrm{~h}$ after each exposure subject underwent a fixed-dose allergen challenge (PD15).

Ten subjects completed the study. The mean early asthmatic responses (maximum percentage change in FEV1 during the first $2 \mathrm{~h}$ after challenge) following air, $100 \mu \mathrm{g} \cdot \mathrm{m}^{-3} \mathrm{H}_{2} \mathrm{SO}_{4}$, and $1,000 \mu \mathrm{g} \cdot \mathrm{m}^{-3} \mathrm{H}_{2} \mathrm{SO}_{4}$, were $-14.1 \%,-16.7 \%$, and $-18.4 \%$, respectively. The difference between $1,000 \mu \mathrm{g} \cdot \mathrm{m}^{-3} \mathrm{H}_{2} \mathrm{SO}_{4}$ and air was significant (mean difference: $-4.3 \%, 95 \%$ confidence interval (CI: $-1.2--7.4 \%, p=0.013$ ). The difference between air and $100 \mu \mathrm{g} \cdot \mathrm{m}^{-3} \mathrm{H}_{2} \mathrm{SO}_{4}$ approached significance (mean difference: $-2.6 \%$, 95\% CI: $0.0--5.3 \%, p=0.051$ ).

These results suggest that, at least at high mass concentration, sulphuric acid can potentiate the early asthmatic response of mild asthmatic subjects to grass pollen allergen, although the effect is limited.

Eur Respir J 2001; 18: 640-646.
\end{abstract}

*Heartlands Research Institute, Heartlands Hospital, Birmingham, UK. \#Division of Environmental Health and Risk Management, University of Birmingham, Edgbaston, Birmingham, UK.

Correspondence: J.G. Ayres, Heartlands Hospital, Bordesley Green East, Birmingham, B9 5SS, UK.

Fax: 441217720292

Keywords: Air pollution

allergen

challenge study

particles

sulphuric acid

Received: October 162000

Accepted after revision June 112001
Several epidemiological studies from both Europe and America have demonstrated an association between day-to-day changes in the concentration of airborne particulate matter and acute health effects [1-6]. These range from increases in respiratory and cardiovascular mortality and hospital admissions, to day-to-day changes in lung function and symptoms. Groups considered to be at increased risk from particulate air pollutant exposure include those with pre-existing respiratory disease, both chronic obstructive pulmonary disease (COPD) [7] and asthma [8], although the association with asthma attacks is less consistent. This may, in part, be due to the variable metrics used to describe particulate exposure [9] and differences in the definition of "attacks" of asthma. In addition, the component(s) or characteristic(s) of the ambient aerosol responsible for health effects remain unclear, although recent interest has focused on smaller particles $(<2.5 \mu \mathrm{m})[10]$.

Particulate sulphates are an important component of the ambient aerosol. They are principally secondary particles, formed when gas phase species react to give rise to products with low vapour pressures, which consequently condense [11]. Their chief source is the atmospheric oxidation of sulphur dioxide $\left(\mathrm{SO}_{2}\right)$ to sulphuric acid $\left(\mathrm{H}_{2} \mathrm{SO}_{4}\right) . \mathrm{H}_{2} \mathrm{SO}_{4}$ exists in air in particle form; it reacts irreversibly in two stages with ammonia gas $\left(\mathrm{NH}_{3}\right)$ to form ammonium bisulphate $\left(\mathrm{NH}_{4} \mathrm{HSO}_{4}\right)$ or ammonium sulphate $\left(\left(\mathrm{NH}_{4}\right)_{2} \mathrm{SO}_{4}\right)$ [12].

Laboratory challenge with particulate $\mathrm{H}_{2} \mathrm{SO}_{4}$ in normal subjects has mostly failed to elicit any response following exposure to concentrations of $\leqslant 1,500 \mu \mathrm{g} \cdot \mathrm{m}^{-3}$, although one study recorded an increase in nonspecific bronchial reactivity $24 \mathrm{~h}$ after a 4-h long exposure to $450 \mu \mathrm{g} \cdot \mathrm{m}^{-3}$ [13]. In subjects with asthma, results are conflicting, with some showing bronchoconstriction after inhalation of concentrations of $\mathrm{H}_{2} \mathrm{SO}_{4}<1,000 \mu \mathrm{g} \cdot \mathrm{m}^{-3}[14,15]$, and in one study, with concentrations of only $100 \mu \mathrm{g} \cdot \mathrm{m}^{-3}$ [16]; most studies [17-19], including the authors' own (unpublished data), have shown no significant effect on lung function.

Ambient $\mathrm{H}_{2} \mathrm{SO}_{4}$ levels are now, in general, low in the UK, but a recent study from CA, USA [20] has identified an association between health effects and day-to-day changes in the concentrations of this 
pollutant. One explanation for the differences between the epidemiological and challenge findings could be an interaction between $\mathrm{H}_{2} \mathrm{SO}_{4}$ and an unmeasured co-pollutant, such as an aeroallergen.

The potential for air pollutants such as ozone $\left(\mathrm{O}_{3}\right)$ and nitrogen dioxide $\left(\mathrm{NO}_{2}\right)$ (with or without $\mathrm{SO}_{2}$ ) to enhance the specific bronchial reactivity of the asthmatic airway to allergen is now well documented [21], and this has been proposed as a possible mechanistic pathway for some of their respiratory health effects in susceptible populations. There have been no previous studies in humans of the effects of $\mathrm{H}_{2} \mathrm{SO}_{4}$ exposure on bronchial responses to allergen. To explore this possibility further, the effect of exposure to $100 \mu \mathrm{g} \cdot \mathrm{m}^{-3}$ and $1,000 \mu \mathrm{g} \cdot \mathrm{m}^{-3}$ highly characterized $\mathrm{H}_{2} \mathrm{SO}_{4}$ aerosol (mass median diameter (MMD) $\sim 300 \mathrm{~nm}$ ) on the early asthmatic responses of subjects with mild asthma to inhaled grass pollen allergen was examined.

\section{Methods}

\section{Subjects}

Thirteen nonsmoking, atopic, asthmatic adult volunteers were studied (table 1). At a baseline screening visit, they underwent skin-prick testing with grass pollen (Bayer, Newbury, Berkshire, UK), positive (histamine) and negative control solutions, spirometry and bronchial challenge to grass pollen allergen (Cocksfoot and Timothy, Bayer). Only subjects that satisfied the following inclusion criteria were recruited: aged 16-60 yrs; nonsmokers; physiciandiagnosed asthma taking inhaled medication only, the dose of inhaled beclomethasone or budesonide not $>500 \mu \mathrm{g} \cdot 24 \mathrm{~h}^{-1}$; baseline forced expiratory volume in one second (FEV1) and a ratio of FEV1 to forced vital capacity (FVC) $\geqslant 70 \%$ predicted [22]; positive skin-prick test (mean wheal diameter $>3 \mathrm{~mm}$ ) to grass pollen; and positive early asthmatic response $(>15 \%$ fall in FEV1 from baseline) to bronchial challenge with grass pollen. All subjects gave written informed consent and the project was approved by the East Birmingham Health Authority Research and Ethics Committee.

\section{Study design}

The grass pollen bronchial challenge dose-response curves at enrolment were used to establish the provocative dose of allergen required to produce a $15 \%$ fall in each subject's FEV1 (PD15) [23]. On three subsequent occasions, $\geqslant 2$ weeks apart, in the presence of a stable baseline, FEV1 subjects underwent an air or $\mathrm{H}_{2} \mathrm{SO}_{4}\left(\right.$ at $100 \mu \mathrm{g} \cdot \mathrm{m}^{-3}$ and $1,000 \mu \mathrm{g} \cdot \mathrm{m}^{-3}$ ) exposure for $1 \mathrm{~h}$ in a randomized, double-blind manner at 19:00 $\mathrm{h}$. This was followed $14 \mathrm{~h}$ later by a fixed-dose allergen challenge, being the PD15 from the enrolment challenge.

\section{Measurements}

Lung function measurements, pre- and postexposure and during allergen challenge, were made using a Fleisch pneumotachograph (Vitalograph, Buckingham, UK) and the Spirotrach III system (Vitalograph) calibrated before each exposure and each bronchial challenge. The best of at least three technically acceptable blows was taken as the measured value at each point. European Community Coal and Steel predicted values were used [22]. Following completion of allergen challenge, subjects were requested to record their FEV1 using a hand-held logging spirometer (Vitalograph 2110 electronic peak expiratory flow (PEF)/ FEV1 diary, Vitalograph), at least hourly while awake for the remainder of the day, to detect any significant change in their lung function beyond the study period.

\section{Bronchial challenge}

Bronchial challenges were made with a breathtriggered Mefar MB3 dosimeter (Markos-Mefar,

Table 1. - Clinical characteristics and experimental details of subjects

\begin{tabular}{|c|c|c|c|c|c|c|c|}
\hline Subject & Sex & Age yrs & $\mathrm{IS}^{\#} \mu \mathrm{g} \cdot \mathrm{day}^{-1}$ & $\begin{array}{l}\text { FEV1 L } \\
\text { (\% pred) }\end{array}$ & $\begin{array}{c}\text { FEV1/FVC } \\
\text { value ( } \% \text { pred) }\end{array}$ & PD15 unit ${ }^{+}$ & Exposure order \\
\hline 1 & $\mathrm{~F}$ & 42 & 200 & $2.15(71)$ & $0.72(83)$ & 3.5 & Air: $1000 \mu \mathrm{g} \cdot \mathrm{m}^{-3}: 100 \mu \mathrm{g} \cdot \mathrm{m}^{-3}$ \\
\hline 2 & $\mathrm{~F}$ & 29 & 400 & $2.93(86)$ & $0.71(82)$ & 100 & $100 \mu \mathrm{g} \cdot \mathrm{m}^{-3}:$ Air $: 1000 \mu \mathrm{g} \cdot \mathrm{m}^{-3}$ \\
\hline $3^{\text {बा }}$ & $\mathrm{F}$ & 24 & nil & $3.12(92)$ & $0.84(96)$ & 64 & $100 \mu \mathrm{g} \cdot \mathrm{m}^{-3}: 1000 \mu \mathrm{g} \cdot \mathrm{m}^{-3}: \mathrm{Air}$ \\
\hline 4 & $\mathrm{~F}$ & 21 & nil & $2.97(103)$ & $0.90(103)$ & 36 & Air:100 $\mu \mathrm{g} \cdot \mathrm{m}^{-3}: 1000 \mu \mathrm{g} \cdot \mathrm{m}^{-3}$ \\
\hline 5 & $\mathrm{~F}$ & 30 & 500 & $2.65(87)$ & $0.81(93)$ & 220 & $1000 \mu \mathrm{g} \cdot \mathrm{m}^{-3}:$ Air: $100 \mu \mathrm{g} \cdot \mathrm{m}^{-3}$ \\
\hline 6 & $\mathrm{~F}$ & 21 & nil & $3.33(98)$ & $0.86(98)$ & 41 & $1000 \mu \mathrm{g} \cdot \mathrm{m}^{-3}: 100 \mu \mathrm{g} \cdot \mathrm{m}^{-3}:$ Air \\
\hline 7 & M & 54 & nil & $2.77(73)$ & $0.71(89)$ & 5 & $100 \mu \mathrm{g} \cdot \mathrm{m}^{-3}:$ Air: $1000 \mu \mathrm{g} \cdot \mathrm{m}^{-3}$ \\
\hline 8 & M & 17 & nil & $3.94(98)$ & $0.85(91)$ & 1500 & $1000 \mu \mathrm{g} \cdot \mathrm{m}^{-3}: 100 \mu \mathrm{g} \cdot \mathrm{m}^{-3}:$ Air \\
\hline 9 & M & 39 & 400 & $4.04(98)$ & $0.74(90)$ & 48 & $1000 \mu \mathrm{g} \cdot \mathrm{m}^{-3}:$ Air: $100 \mu \mathrm{g} \cdot \mathrm{m}^{-3}$ \\
\hline 10 & $\mathrm{~F}$ & 29 & 400 & $2.82(86)$ & $0.77(88)$ & 24 & Air: $1000 \mu \mathrm{g} \cdot \mathrm{m}^{-3}: 100 \mu \mathrm{g} \cdot \mathrm{m}^{-3}$ \\
\hline 11 & $\mathrm{~F}$ & 32 & nil & 3.49 (112) & $0.86(100)$ & 8 & $100 \mu \mathrm{g} \cdot \mathrm{m}^{-3}: 1000 \mu \mathrm{g} \cdot \mathrm{m}^{-3}: \mathrm{Air}$ \\
\hline $12^{\bullet}$ & $\mathrm{F}$ & 40 & nil & $2.12(92)$ & $0.73(85)$ & 7 & Air: $100 \mu \mathrm{g} \cdot \mathrm{m}^{-3}: 1000 \mu \mathrm{g} \cdot \mathrm{m}^{-3}$ \\
\hline 13 & M & 27 & nil & $3.97(94)$ & $0.82(98)$ & 17 & $100 \mu \mathrm{g} \cdot \mathrm{m}^{-3}:$ Air: $1000 \mu \mathrm{g} \cdot \mathrm{m}^{-3}$ \\
\hline
\end{tabular}

IS: inhaled steroid; FEV1: forced expiratory volume in one second; FVC: forced vital capacity; \% pred: percentage of predicted; PD15: provocative dose causing a 15\% fall in FEV1; F: female; M: male. \#: IS $\mu \mathrm{g} \cdot$ day $^{-1}$ of beclomethasone or equivalent; ${ }^{\uparrow}$ : subjects who failed to complete the study; ${ }^{+}: 1$ breath unit defined as five inhalations of a $50 \mathrm{unit} \cdot \mathrm{mL}^{-1}$ solution (arbitrary units). 
Bovezzo, Italy). They were not performed within 4 weeks of an upper respiratory tract infection. Those subjects using inhaled steroid medication discontinued them on the day of exposure $(\geqslant 24 \mathrm{~h}$ prior to allergen challenge) and recommenced them at completion of their allergen challenge the following day. Antihistamine medication was discontinued for $\geqslant 1$ week before each challenge and subjects maintained their usual daily consumption of ascorbic acid of caffeinecontaining foodstuffs for the duration of the study. Dosimeter activation was set to $0.6 \mathrm{~s}$ during five consecutive full inspirations from functional residual capacity, followed by a $10 \mathrm{~s}$ breath-hold for each concentration of allergen. Each subject used the same nebulizer and their own trigger sensitivities throughout the study. At the start of each challenge, FEV1 was measured before and 1 min after diluent (phosphate buffered saline) delivery. If the values differed by $<5 \%$, the postdiluent FEV1 value was taken as baseline for that study day. If the value following diluent was $\geqslant 15 \%$ lower than the prediluent value, the challenge was abandoned for that day. If neither criterion was met, the procedure was repeated until one had been fulfilled. The same batch of grass pollen allergen was used throughout the study. One breath unit of allergen was defined as a single inhalation of a 50 units $\cdot \mathrm{mL}^{-1}$ solution. All challenges were avoided during the pollen season.

On the preliminary assessment day, doubling incremental concentrations of allergen were delivered, with FEV1 measurements 3, 5, and $10 \mathrm{~min}$ after each fiveinhalation cycle until a fall in the postdiluent FEV1 of $>15 \%$ was achieved. A dose-response curve was drawn for each subject and interpolation used to establish the PD15. This cumulative dose was used in that subject's series of allergen challenges. The provocative dose was divided into two or three five-breath deliveries so that the challenge could be abandoned prematurely if necessary. On completion of allergen delivery, FEV1 measurements were made at 20,40, and $60 \mathrm{~min}$ and then hourly for $7 \mathrm{~h}$. If symptoms or recordings indicated a decline in FEV1, recordings were made more frequently.

The maximum reduction in FEV1 (percentage change from postdiluent FEV1) during the first $2 \mathrm{~h}$ after allergen inhalation was taken as the early asthmatic response. After recovery of FEV1 towards baseline, any subsequent fall in FEV1 (expressed as percentage change from postdiluent FEV1) was also recorded and defined as the late asthmatic response [24].

\section{Exposures}

Exposures were $\geqslant 2$ weeks apart, of an hour's duration at rest and conducted at the same time of day for each individual. The pollutants were calculated to provide concentrations of $100 \mu \mathrm{g} \cdot \mathrm{m}^{-3}$ or $1,000 \mu \mathrm{g} \cdot \mathrm{m}^{-3}$ particulate $\mathrm{H}_{2} \mathrm{SO}_{4}$ (MMD $300 \mathrm{~nm}$ ). All exposures were conducted via a purpose-built, head-only exposure system with an integral particle generator and a head dome [25] (fig. 1). Flow through the system for each exposure was maintained at $120 \mathrm{~L} \cdot \mathrm{min}^{-1}$ to prevent any significant re-breathing within the head

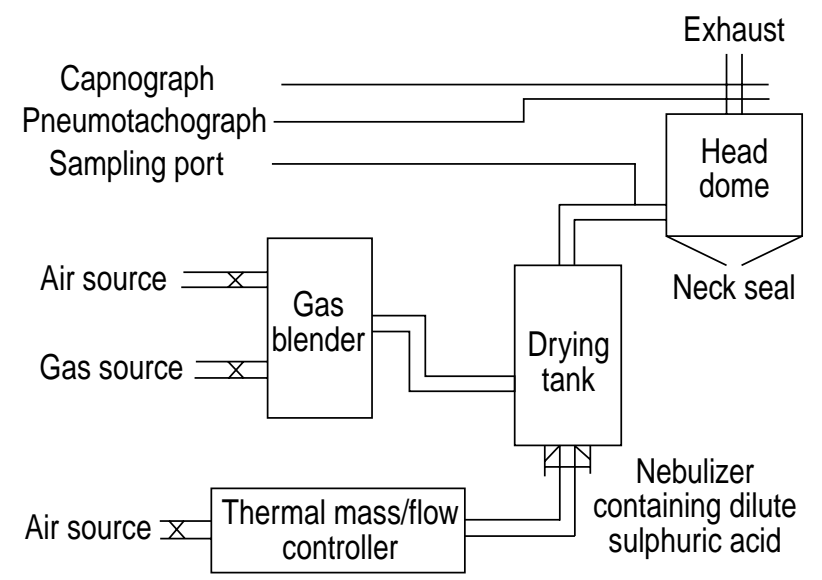

Fig. 1.- Particle generator and exposure system. Gas blender: thermal mass/flow controller regulating turbulent carrier flow of dry medical air to $120 \mathrm{~L} \cdot \mathrm{min}^{-1}$; Thermal mass/flow controller: controller regulating nebulizer driving gas flow, for each mass concentration flow $=4.5 \mathrm{~L} \cdot \mathrm{min}^{-1}$; Nebulizer containing dilute sulphuric acid: MicroCirrus nebulizer (Intersurgical Ltd); Drying tank: $25 \mathrm{~L}$ drying chamber allowing mixing of nebulizer output with turbulent carrier stream.

dome. A technical description of the performance of the particle generator will be published elsewhere (unpublished data), but, in brief, the exposure aerosols were generated using a standard medical Micro Cirrus nebulizer (Intersurgical Ltd, Wokingham, UK) driven by bottled medical air under mass flow control and containing a dilute solution of the $\mathrm{H}_{2} \mathrm{SO}_{4}$. Its output was mixed with a dry, turbulent carrier stream of bottled air in a drying chamber and delivered to the breathing zone of the volunteer. The mass concentrations of the exposure aerosols were determined by the concentration of the material in the nebulizer solution and verified by sampling on a polytetrafluoroethylene filter (Whatman International Ltd, Maidstone, Kent, UK), followed by extraction into distilled deionized water and analysis of sulphates by ion chromatography. The aerosols were also characterized by electrical low pressure impaction, micro orifice uniform deposit impaction and scanning mobility particle sizing. For air (placebo) exposures, the nebulizer ran containing deionized water. For each exposure, the subject was required to sit in a comfortable chair with their head contained within a cast acrylic dome. The entry port in the wall of the dome was positioned within the breathing zone and the exit port was in the roof of the dome. A neck seal was achieved with a modified diving suit neck piece. Before each exposure, subjects brushed their teeth and gargled with an antiseptic mouth rinse to reduce the possibility of neutralization of the exposure aerosols by oral ammonia.

\section{Data analysis}

Based on previous experience of early asthmatic responses following repeated fixed-dose allergen challenge (PD15) [26], it was estimated that a sample size of at least nine subjects was required to detect a difference in response of similar magnitude 
(4-5\% in absolute terms) to that observed for gaseous pollutants. Matched-pair analysis was used to compare FEV1 values following the bronchial challenges. Paired t-tests were used for significance testing. A p-value of $<0.05$ was considered statistically significant.

\section{Results}

Demographic and baseline spirometric details of the study participants are shown in table 1 , as are their respective exposure orders and provocative doses of allergen. All exposures were well tolerated and there were no significant changes in FEV1 or FVC with any exposure (data available on request).

Three subjects failed to complete the study; two due to a significant deterioration in their asthma control following their first and second fixed-dose allergen challenge, respectively. The third withdrew due to the development of another, unrelated medical condition. Their results are excluded from the data analysis.

\section{Aerosol characteristics}

Temperature and relative humidity were measured in the head dome and logged at the beginning of and at 5 min intervals during each exposure. The mean (range) temperature and relative humidity for the exposures are listed in table 2 . In addition, the median mass of $\mathrm{H}_{2} \mathrm{SO}_{4}$ recovered from a random selection of filter trapped samples, five for each type of exposure, collected during actual exposures are displayed in table 2. There were no significant differences in temperature or relative humidity between the exposures, and the recovered median masses $\left(107 \mu \mathrm{g} \cdot \mathrm{m}^{-3}\right.$ and $1,144 \mu \mathrm{g} \cdot \mathrm{m}^{-3}$ ) fitted closely with those required by the authors.

The active exposure aerosols were characterized at the beginning of the study. Superimposed representative outputs of the instruments used are shown in figures $2 \mathrm{a}$ and $2 \mathrm{~b}$. The outputs were broadly concordant; for both mass concentrations, the MMD of the aerosols was $\sim 300 \mathrm{~nm}$. The vast majority of particles were submicronic, with the count mode for each aerosol lying around $30 \mathrm{~nm}$.

\section{Changes in lung function}

There were no significant differences in baseline postdiluent FEV1 values after the various exposures.
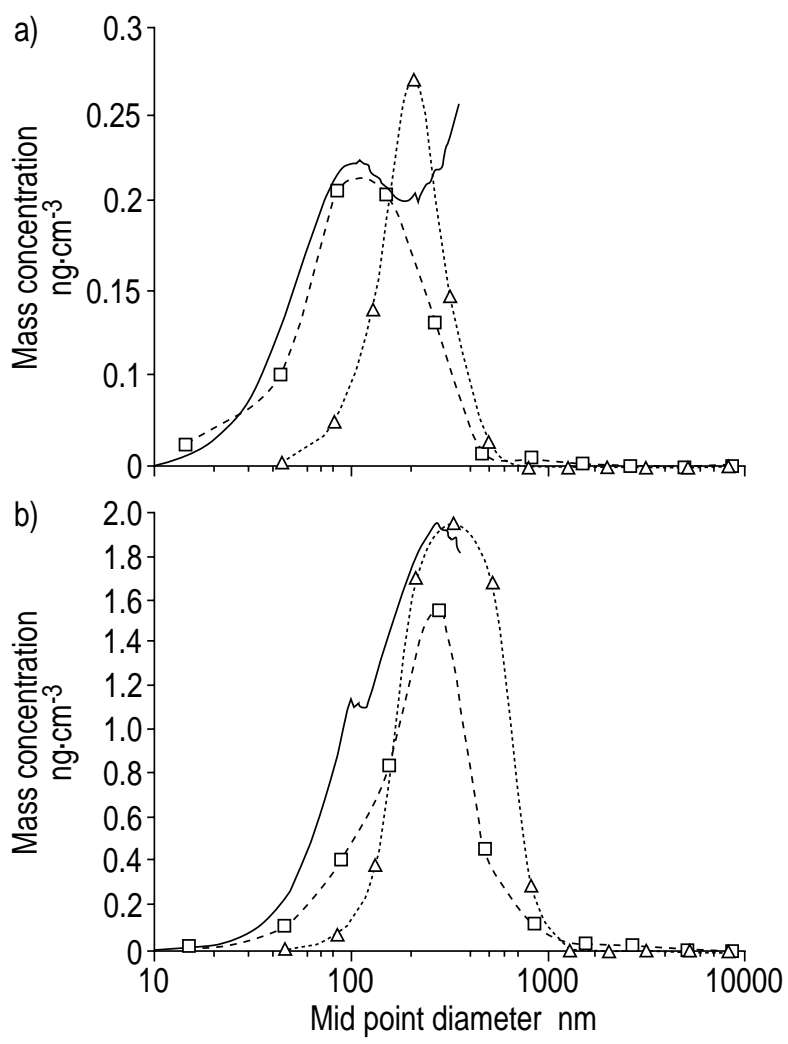

Fig. 2.-Exposure aerosol characteristics. Scaled superimposed outputs from Electrical Low Pressure Impaction (ELPI; $\triangle$ ), Micro Orifice Uniform Deposit Impaction (MOUDI; $\square$ ) and Scanning Mobility Particle Sizing (SMPS; -) devices. a) Low dose sulphuric acid $\left(\mathrm{H}_{2} \mathrm{SO}_{4}\right) \quad 100 \mu \mathrm{g} \cdot \mathrm{m}^{-3}$ and b) high dose $\mathrm{H}_{2} \mathrm{SO}_{4}$ $1,000 \mu \mathrm{g} \cdot \mathrm{m}^{-3}$.

Matched pair analysis demonstrated a significant difference of $-4.3 \%(95 \%$ confidence interval (CI): $-1.2--7.4 \%, \mathrm{p}=0.013$, table 3 ) between the early asthmatic response following air and following $1,000 \mu \mathrm{g} \cdot \mathrm{m}^{-2} \mathrm{H}_{2} \mathrm{SO}_{4}$ exposures. The difference in early response following air and following $100 \mu \mathrm{g} \cdot \mathrm{m}^{-3}$ $\mathrm{H}_{2} \mathrm{SO}_{4}$ exposures of $-2.6 \%$ failed to achieve statistical significance $(95 \% \mathrm{CI}: 0.0--5.3 \%, \mathrm{p}=0.051)$. There was no significant difference between the early responses following the $100 \mu \mathrm{g} \cdot \mathrm{m}^{-3}$ and $1,000 \mu \mathrm{g} \cdot \mathrm{m}^{-3} \mathrm{H}_{2} \mathrm{SO}_{4}$ exposures.

The mean late asthmatic response following air exposures was $-6.0 \%,-5.5 \%$ following $100 \mu \mathrm{g} \cdot \mathrm{m}^{-3}$ $\mathrm{H}_{2} \mathrm{SO}_{4}$ exposures and $-6.7 \%$ following $1,000 \mu \mathrm{g} \cdot \mathrm{m}^{-3}$ $\mathrm{H}_{2} \mathrm{SO}_{4}$ exposures. There were no significant differences between these values (table 4).

Table 2. - Physical properties of exposure aerosols

\begin{tabular}{lccc}
\hline Exposure & Temperature ${ }^{\circ} \mathrm{C}$ & $\begin{array}{c}\text { Relative } \\
\text { humidity } \%\end{array}$ & $\begin{array}{c}\text { Mass concentration } \\
\mathrm{H}_{2} \mathrm{SO}_{4} \mu \mathrm{g} \cdot \mathrm{m}^{-3} \text { median (IQ range) }\end{array}$ \\
\hline Air (placebo) & $17.1(15.92-18.54)$ & $14.8(9.91-15.89)$ & 0.0 \\
$100 \mu \mathrm{g} \cdot \mathrm{m}^{-3} \mathrm{H}_{2} \mathrm{SO}_{4}$ & $16.8(15.86-18.13)$ & $15.0(9.92-15.76)$ & $107(102-111)$ \\
$1000 \mu \mathrm{g} \cdot \mathrm{m}^{-3} \mathrm{H}_{2} \mathrm{SO}_{4}$ & $16.7(15.77-17.92)$ & $14.6(9.82-16.02)$ & $1144(1080-1248)$ \\
\hline
\end{tabular}

Data are presented as mean (range) unless otherwise stated. $\mathrm{H}_{2} \mathrm{SO}_{4}$ : sulphuric acid; IQ: interquartile (range). 
Table 3. - Early asthmatic response

\begin{tabular}{|c|c|c|c|c|c|c|c|c|c|}
\hline \multirow[t]{2}{*}{ Subject } & \multicolumn{3}{|c|}{ Air } & \multicolumn{3}{|c|}{$100 \mu \mathrm{g} \cdot \mathrm{m}^{-3} \mathrm{H}_{2} \mathrm{SO}_{4}$} & \multicolumn{3}{|c|}{$1000 \mu \mathrm{g} \cdot \mathrm{m}^{-3} \mathrm{H}_{2} \mathrm{SO}_{4}$} \\
\hline & $\begin{array}{c}\text { Baseline } \\
\text { FEV1 }\end{array}$ & $\begin{array}{l}\text { Minimum } \\
\text { FEV1 }\end{array}$ & $\%$ change & $\begin{array}{c}\text { Baseline } \\
\text { FEV1 }\end{array}$ & $\begin{array}{l}\text { Minimum } \\
\text { FEV1 }\end{array}$ & $\%$ change & $\begin{array}{c}\text { Baseline } \\
\text { FEV1 }\end{array}$ & $\begin{array}{l}\text { Minimum } \\
\text { FEV1 }\end{array}$ & $\%$ change \\
\hline 1 & 1.94 & 1.66 & -14.43 & 2.10 & 1.56 & -25.71 & 2.05 & 1.47 & -28.29 \\
\hline 2 & 2.80 & 2.39 & -14.64 & 2.82 & 2.38 & -15.60 & 2.86 & 2.20 & -23.08 \\
\hline 4 & 2.85 & 2.42 & -15.09 & 2.97 & 2.45 & -17.51 & 3.11 & 2.55 & -18.01 \\
\hline 5 & 2.79 & 2.47 & -11.47 & 2.37 & 2.03 & -14.35 & 2.45 & 2.06 & -15.92 \\
\hline 6 & 3.31 & 2.81 & -15.11 & 3.24 & 2.59 & -20.06 & 3.30 & 2.72 & -17.58 \\
\hline 7 & 2.81 & 2.43 & -13.52 & 2.75 & 2.38 & -13.45 & 2.78 & 2.42 & -12.95 \\
\hline 8 & 3.96 & 3.58 & -9.60 & 3.81 & 2.36 & -11.81 & 4.12 & 3.59 & -12.86 \\
\hline 10 & 2.81 & 2.31 & -17.79 & 2.76 & 2.21 & -19.93 & 2.64 & 2.17 & -17.80 \\
\hline 11 & 3.01 & 2.51 & -16.61 & 2.93 & 2.53 & -13.65 & 2.89 & 2.37 & -17.99 \\
\hline 13 & 3.62 & 3.17 & -12.43 & 3.55 & 3.02 & -14.93 & 3.67 & 2.97 & -19.07 \\
\hline Mean & 2.99 & 2.58 & -14.1 & 2.93 & 2.45 & $-16.7^{\#}$ & 2.99 & 2.45 & $-18.4^{\star}$ \\
\hline
\end{tabular}

$\mathrm{H}_{2} \mathrm{SO}_{4}$ : sulphuric acid; $\mathrm{FEV} 1$ : forced expiratory volume in one second. ${ }^{*}$ : $\mathrm{p}=0.051$ against air exposure; ${ }^{\text {}}$ : $\mathrm{p}=0.013$ against air exposure.

\section{Discussion}

These results suggest that, at least at high mass concentration $\left(1,000 \mu \mathrm{g} \cdot \mathrm{m}^{-3}\right)$, fine particulate $\mathrm{H}_{2} \mathrm{SO}_{4}$ can potentiate the early asthmatic response of asthma patients to inhaled grass pollen allergen. They are broadly concordant with the observations of BYLIN et al. [27] of enhancement of early asthmatic responses to birch pollen in asthmatic volunteers exposed to particulate matter (particles with a $50 \%$ cut-off aerodynamic diameter of $\left.2.5 \mu \mathrm{m}(\mathrm{PM} 2.5)>100 \mu \mathrm{g} \cdot \mathrm{m}^{-3}\right)$ and $\mathrm{NO}_{2}\left(>300 \mu \mathrm{g} \cdot \mathrm{m}^{-3}\right)$ in a road tunnel. The effect size $(-4.3 \%)$ that was observed is small, but it is similar to that observed for the potentiating effect of other pollutants, such as $\mathrm{O}_{3}$ and $\mathrm{NO}_{2}$, on the early airway response of asthmatics challenged with allergen, when examined in studies of similar design [27, 28]. This may reflect a limitation of this sort of study design, in that it prevents assessment of any change in the slope of the dose-response curve for allergen. Alternatively, it raises the question of whether air pollutants might be able to exert an "all or nothing" effect on what might prove to be a finite response of asthmatic airways to air pollutants. Nonetheless, these results may offer a potential explanation for the observed association between particulate air pollution and exacerbations of asthma at a population level. Unfortunately, despite the use of a highly characterized aerosol, these results do not allow the authors to conclude whether the observed effect might be dependent on the simple presence of particles or on their chemical composition or acidity.

Mechanisms to produce the observed changes are not clear. Theoretically they may reflect changes in the permeability of the respiratory epithelium to allergen [29], the priming or activation of cellular and/or chemical cascades involved in allergen handling [30], or even dynamic changes in the autonomic control of airway tone, in response to pollutant exposure [31]. The finding that allergen responsiveness exposure is affected $14 \mathrm{~h}$ after $\mathrm{H}_{2} \mathrm{SO}_{4}$, suggests a long-lasting priming effect. This mechanistic uncertainty is further compounded by the limited understanding of the fate of exposure aerosols once they have been inhaled, despite the rigor with which the authors have attempted to characterize them. It remains unclear

Table 4. - Late asthmatic response

\begin{tabular}{|c|c|c|c|c|c|c|c|c|c|}
\hline \multirow[t]{2}{*}{ Subject } & \multicolumn{3}{|c|}{ Air } & \multicolumn{3}{|c|}{$100 \mu \mathrm{g} \cdot \mathrm{m}^{-3} \mathrm{H}_{2} \mathrm{SO}_{4}$} & \multicolumn{3}{|c|}{$1000 \mu \mathrm{g} \cdot \mathrm{m}^{-3} \mathrm{H}_{2} \mathrm{SO}_{4}$} \\
\hline & $\begin{array}{l}\text { Baseline } \\
\text { FEV1 }\end{array}$ & $\begin{array}{c}\text { Minimum } \\
\text { FEV1 }\end{array}$ & $\%$ change & $\begin{array}{l}\text { Baseline } \\
\text { FEV1 }\end{array}$ & $\begin{array}{c}\text { Minimum } \\
\text { FEV1 }\end{array}$ & $\%$ change & $\begin{array}{l}\text { Baseline } \\
\text { FEV1 }\end{array}$ & $\begin{array}{c}\text { Minimum } \\
\text { FEV1 }\end{array}$ & $\%$ change \\
\hline 1 & 1.94 & 1.78 & -8.25 & 2.10 & 1.92 & -8.57 & 2.05 & 1.78 & -13.17 \\
\hline 2 & 2.80 & 2.48 & -11.43 & 2.82 & 2.42 & -14.18 & 2.86 & 2.51 & -12.24 \\
\hline 4 & 2.85 & 2.85 & 0.00 & 2.97 & 2.87 & -3.37 & 3.11 & 3.11 & 0.00 \\
\hline 5 & 2.79 & 2.63 & -5.73 & 2.37 & 2.37 & 0.00 & 2.45 & 2.45 & 0.00 \\
\hline 6 & 3.31 & 2.88 & -12.99 & 3.24 & 3.02 & -6.79 & 3.30 & 2.80 & -15.15 \\
\hline 7 & 2.81 & 2.81 & 0.00 & 2.75 & 2.62 & -4.73 & 2.78 & 2.78 & 0.00 \\
\hline 8 & 3.96 & 3.96 & 0.00 & 3.81 & 3.81 & 0.00 & 4.12 & 4.02 & -2.43 \\
\hline 10 & 2.81 & 2.64 & -6.05 & 2.76 & 2.61 & -5.43 & 2.64 & 2.47 & -6.44 \\
\hline 11 & 3.01 & 2.88 & -4.32 & 2.93 & 2.93 & 0.00 & 2.89 & 2.78 & -3.81 \\
\hline 13 & 3.62 & 3.22 & -11.05 & 3.55 & 3.14 & -11.55 & 3.67 & 3.18 & -13.35 \\
\hline Mean & 2.99 & 2.81 & -6.0 & 2.93 & 2.77 & -5.5 & 2.99 & 2.79 & -6.7 \\
\hline
\end{tabular}

$\mathrm{H}_{2} \mathrm{SO}_{4}$ : sulphuric acid; FEV1: forced expiratory volume in one second. There were no significant differences in the late asthmatic responses between exposures. 
to what extent the aerosols will be modified by exposure to the humid environment of the human airway. Individual particles may be subject to growth and this might be expected to have significant effects on their regional deposition within the respiratory tract. Such uncertainty is mirrored by the authors' limited knowledge of the regional fate of the ambient aerosol in the normal human airway [12] and in the presence of disease states such as COPD [32].

The authors failed to detect any significant effect of particulate $\mathrm{H}_{2} \mathrm{SO}_{4}$ exposure on the late asthmatic responses of the volunteers. The study was not designed to test this hypothesis as subjects were recruited on the basis of their early asthmatic responses. No conclusions about the effect of $\mathrm{H}_{2} \mathrm{SO}_{4}$ exposure on the late asthmatic response can be drawn.

In the UK, sulphates account for $20-25 \%$ of urban, total suspended master by mass [11], of which $85 \%$ is in the fine $(<2.5 \mu \mathrm{m})$ fraction. In the USA, sulphates comprise $20-40 \%$ of measured particles with a $50 \%$ cut-off aerodynamic diameter of $10 \mu \mathrm{m}$ (PM10) [33]. Few measurements of atmospheric $\mathrm{H}_{2} \mathrm{SO}_{4}$ concentrations have been made in the UK, and most were made in the 1950s and 1960s. In a more recent study from rural Essex, the peak concentration recorded over a 62 day period in 1987 was $8.7 \mu \mathrm{g} \cdot \mathrm{m}^{-3}$ [34]. Data from rural sites in North America have shown higher values, with maximum daily means $\leqslant 15 \mu \mathrm{g} \cdot \mathrm{m}^{-3}$ in the summer months during 1983-1986, and values of $\leqslant 27 \mu \mathrm{g} \cdot \mathrm{m}^{-3}$ over shorter periods in the late 1970s [35]. Maximum hourly average urban concentrations in the UK now rarely rise $>50 \mu \mathrm{g} \cdot \mathrm{m}^{-3}$, although earlier this century, hourly averages may at times have exceeded $1,000 \mu \mathrm{g} \cdot \mathrm{m}^{-3}$.

In summary, the authors have shown potentiation of the early asthmatic response to grass pollen allergen of subjects with mild asthma by particulate sulphuric acid, and that the degree of this potentiation is similar to that previously shown for nitrogen dioxide and ozone. The reasons for this are not clear, but exploration of sulphuric acid exposures in the presence of other pollutants (including insoluble particles), and, possibly, studies of the autonomic consequences of such exposures, are needed to elucidate the likely mechanisms and to determine how these volunteer studies might relate to real-life exposures.

\section{References}

1. Pope CA, Schwartz J, Ransom MR. Daily mortality and PM10 pollution in Utah Valley. Arch Environ Health 1992; 47: 211-217.

2. Schwartz J, Slater D, Larson TV, Pierson WE, Koenig JQ. Particulate air pollution and hospital emergency room visits for asthma in Seattle. Am Rev Respir Dis 1993; 147: 826-831.

3. Hoek G, Brunekreef B. Acute effects of a winter air pollution episode on pulmonary function and respiratory symptoms of children. Arch Environ Health 1993; 48: $328-335$.

4. Schwartz J. Air pollution and hospital admissions for the elderly in Detroit. Am J Respir Crit Care Med 1994; 150: 648-655.
5. Dockery DW, Pope CA. Acute respiratory effects of particulate pollution. Annu Rev Public Health 1994; 15: 107-132.

6. Katsouyanni K, Touloumi G, Spix C, et al. Short term effects of ambient sulphur dioxide and particulate matter on mortality in 12 European cities: results from time series data from the APHEA project. BMJ 1997; 314: $1658-1663$

7. Schwartz J, Dockery DW. Increased mortality in Philadelphia associated with daily air pollution concentrations. Am Rev Respir Dis 1992; 145: 600-604.

8. Roemer W, Hoek G, Brunekreef B. Effect of ambient winter air pollution on respiratory health of children with chronic respiratory symptoms. Am Rev Respir Dis 1993; 147: 118-124.

9. Department of Health. Quantification of the effects of air pollution on health in the United Kingdom. London, HMSO, 1998.

10. Ayres JG. Particle mass or particle numbers? Eur Respir Rev 1998; 53: 135-138.

11. Department of Health. Non-biological particles and health. London, HMSO, 1995.

12. Department of Health. Sulphur dioxide acid aerosols and particulates. London, HMSO, 1992.

13. Utell MJ, Morrow PE, Hyde RW. Airway reactivity to sulfate and sulfuric acid aerosols in normal and asthmatic subjects. JAPCA 1984; 34: 931-935.

14. Utell MJ, Morrow PE, Speers DM, Darling J, Hyde RW. Airway responses to sulfate and sulfuric acid aerosols in asthmatics. Am Rev Respir Dis 1983; 128: $444-450$.

15. Avol EL, Linn WS, Whynot JD, et al. Respiratory dose-response study of normal and asthmatic volunteers exposed to sulfuric acid aerosol in the submicrometer size range. Toxicol Ind Health 1988; 4: 173-184.

16. Koenig JQ, Pierson WE, Horike M. The effects of inhaled sulfuric acid on pulmonary function in adolescent asthmatics. Am Rev Respir Dis 1983; 128: 221-225.

17. Sackner MA, Ford D, Fernandez R, et al. Effects of sulfuric acid aerosol on cardiopulmonary function of dogs, sheep and humans. Am Rev Respir Dis 1978; 118: 497-510.

18. Linn WS, Avol EL, Shamoo DA, Whynot JD, Anderson KR, Hackney JD. Respiratory responses of exercising asthmatic volunteers exposed to sulfuric acid aerosol. JAPCA 1986; 36: 1323-1328.

19. Aris R, Christian D, Sheppard D, Balmes JR. Lack of bronchoconstrictor response to sulfuric acid aerosols and fogs. Am Rev Respir Dis 1991; 143: 744-750.

20. Ostro BD, Lipsett MJ, Weiner MB, Selner JC. Asthmatic responses to airborne acid aerosols. Am J Public Health 1991; 81: 694-702.

21. Devalia JL, Rusznak C, Wang J, Davies RJ. Pollutionallergen interactions: challenge studies in man. Eur Respir Rev 1998; 53: 175-178.

22. Quanjer $\mathrm{PhH}$, ed. Standardized lung function testing. Report of working party standardization of lung function tests, European Community for Coal and Steel. Bull Eur Physiopathol Respir 1983; 19: Suppl. 5, 1-95.

23. Cockcroft DW, Murdock KY, Mink JT. Determination of histamine PC20: comparison of linear and logarithmic interpolation. Chest 1983; 84: 505-506.

24. Cavigioli G, Mastropasqua B, Pelucchi A, Marazzini L, Foresi A. Reproducibility of allergen induced asthma and associated increase in bronchial responsiveness 
to methacholine in asthmatic children. Ann Allergy 1993; 70: 411-417.

25. Tunnicliffe WS, Mark D, Harrison R, Ayres JG. A system for the generation and head-only delivery of submicronic particles for the study of the health effects of particulate air pollution. Eur Respir J 1998; 12: Suppl. 28, 335s.

26. Tunnicliffe WS, Burge PS, Ayres JG. Effect of domestic concentrations of nitrogen dioxide on airway responses to inhaled allergen in asthmatic subjects. Lancet 1994; 344: 1733-1736.

27. Bylin G, Svartengren M, Strand V, Järup L, Pershagen G. A short-term exposure to air pollution in a road tunnel enhances the asthmatic response to allergen. Part two - health effects. Eur Respir J 1998; 12: Suppl. $28,259 \mathrm{~s}$.

28. Molfino NA, Wright SC, Katz I, et al. Effect of low concentrations of ozone on inhaled allergen responses in asthmatic subjects. Lancet 1991; 338: 199-203.

29. Devalia JL, Sapsford RJ, Cundell DR, Rusznak C, Campbell AM, Davies RJ. Human bronchial cell dysfunction following in vitro exposure to nitrogen dioxide. Eur Respir J 1993; 6: 1308-1316.
30. Peden DB, Setzer RW Jr, Devlin RB. Ozone exposure has both a priming effect on allergen-induced responses and an intrinsic inflammatory action in the nasal airways of perennially allergic asthmatics. $\mathrm{Am}$ J Respir Crit Care Med 1995; 151: 1336-1345.

31. Tunnicliffe WS, Hilton M, Ayres JG. The effect of sulphur dioxide $\left(\mathrm{SO}_{2}\right)$ exposure on indices of heart rate variability (HRV) in normal and asthmatic adults. Eur Respir $J$ 2001; 17: 604-608.

32. Bennett WD, Zeman KL, Kim C, Mascarella J. Enhanced deposition of fine particles in COPD patients spontaneously breathing at rest. Inhal Toxicol 1997; 9: 1-14.

33. Spengler J, Wilson R. Emissions, dispersion, and concentration of particles. In: Spengler J, Wilson R, eds. Particles in Our Air: Concentrations and Health Effects. Boston, Harvard University Press, 1996.

34. Kitto AMN, Harrison RM. Processes affecting concentrations of aerosol strong acidity at sites in eastern England. Atmos Environ 1992; 26: 2389-2399.

35. Lioy PJ, Waldman JM. Acidic sulphate aerosols: characterisation and exposure. Environ Health Perspect 1989; 79: 15-34. 